\section{Is COVID-19 a turning point in stopping global sourcing? Differentiating between declining continental and increasing transcontinental sourcing}

\author{
Thomas Koerber and Holger Schiele \\ Department of Entrepreneurship/Technology/Management (ETM), \\ University of Twente, Enschede, The Netherlands
}

Turning point in stopping global sourcing

Received 21 February 2021 Revised 29 June 2021 7 August 2021 Accepted 10 August 2021

\begin{abstract}
Purpose - This research aims to investigate the impact of the current COVID-19 pandemic (C19, Corona) on trends of transcontinental sourcing as an extreme form of global sourcing. This study starts by observing that the sideward movement of international trade in the past decade can be differentiated into an increase in transcontinental sourcing and a relative decline of intra-EU sourcing. By differentiating between continental and transcontinental sourcing, this study gains insights into global sourcing trends and conducts a finegrained analysis of the impact of COVID-19.

Design/methodology/approach - After analysing Eurostat statistics, the authors conducted 21 semistructured interviews with companies from multiple industry sectors affected by a high share of transcontinental suppliers. Using the Gioia method, data from the interviews were structured. By examining the identified motives, challenges and solutions, the authors analyse the impact of COVID-19 on transcontinental sourcing.

Findings - The COVID-19 pandemic seems not to represent a turning point stopping global sourcing. The authors did not find evidence for a trend reversal. Most of the interviewed companies share the opinion that transcontinental sourcing will remain important or slightly increase in the future. Based on the analysis of their specific motives for transcontinental sourcing, it became clear that factors supportive as well as detrimental to transcontinental sourcing are levelling each other out.

Originality/value - To the best of the authors' knowledge, this is the first study explicitly differentiating between continental and transcontinental sourcing as different types of global sourcing. While in European sourcing, a decreasing trend is already evident, as shown by our data analysis, there is a lack of investigations addressing transcontinental sourcing. In this study, the authors concentrated on motives, challenges and solutions of transcontinental sourcing. Extending beyond the immediate COVID-19 impact assessment, findings suggest that purchasing would benefit from treating transcontinental, remote sourcing as a distinct process from continental sourcing, particularly intra-EU-sourcing.
\end{abstract}

Keywords Qualitative, Impacts, Trends, Global sourcing, Covid-19, European sourcing may suit better, Transcontinental sourcing

Paper type Research paper

(C) Thomas Koerber and Holger Schiele. Published by Emerald Publishing Limited. This article is published under the Creative Commons Attribution (CC BY 4.0) licence. Anyone may reproduce, distribute, translate and create derivative works of this article (for both commercial and noncommercial purposes), subject to full attribution to the original publication and authors. The full terms of this licence maybe seen at http://creativecommons.org/licences/by/4.0/legalcode 
JGOSS

15,2

220

\section{Introduction: challenges to the continuation of the trend to increase global sourcing}

For at least three decades, globalisation has been a steady trend, which, from a purchasing perspective, means the rising importance of global sourcing as an element of commodity strategies. However, with the COVID-19 crisis, whether the globalisation trend will continue or might be reversed is increasingly being discussed.

Global sourcing, understood as buying from suppliers located outside the own country, has been an essential component for purchasing departments and generates benefits including cost savings, procurement of innovative products, as well as, eventually, anticipating sales opportunities (Bozarth et al., 1998; Schiele et al., 2011; Smith, 1999; Steinle and Schiele, 2008; Trent and Monczka, 2003a). The importance of global sourcing grew throughout the last decades (Giunipero et al., 2019; Quintens et al., 2006). However, already before the Corona crisis, it has been argued that global value chain intensity seems to have been reaching a plateau (Auer et al., 2017). A trend to stagnation of world trade has been discussed (Altuzarra et al., 2020). Therefore, reshoring due to increasing costs in third world countries, but also deep localisation, i.e. increasing value creation in the developing countries replacing imports and hence reducing world trade (Bohnenkamp et al., 2020), became more popular (Altuzarra et al., 2020; Kinkel, 2012; Schiele, Hoffmann and Korber, 2020).

The COVID-19 crisis raises serious challenges for purchasing companies concerning global sourcing. The crisis caused supply chain interruptions and included the risk of delivery failures. The pandemic especially hit those buying firms relying on single sourcing and strong dependencies on remote suppliers (Baldwin and Tomiura, 2020). As a consequence of global instability, it is assumed that supply chains need to become more flexible and adaptive (Buatois and Cordon, 2020). Regionalisation and a higher capacity in the home country are identified as options to reduce the risk of global sourcing (Gereffi, 2020). The pandemic currently appears to slow down global sourcing (Altuzarra et al., 2020).

Regarding the challenge to the manta of ever-increasing globalisation, the following question with considerable interest for purchasers arises:

RQ1: Is the current pandemic a turning point stopping global sourcing or just a temporary drop in globalisation?

RQ2: Is COVID-19 likely to disrupt global sourcing and ask for new, more localised sourcing strategies?

This paper will first dissect "global souring" into continental and transcontinental sourcing to elaborate on localisation recommendation for future sourcing strategies. In our case, continental sourcing means intra-European sourcing, which roughly averages to half of the global sourcing volume of European firms (Alajääskö, 2009; Bengtsson et al., 2009). This novel distinction is important, as we will show that European sourcing was losing importance already in the past, while transcontinental sourcing increased in importance. To understand the future of global sourcing, hence, it is worth focusing on the transcontinental part. If COVID-19 severely hampered transcontinental sourcing, we could expect an overall decrease in international trade. Hence, investigating transcontinental sourcing will lead us to more clear answers regarding the research questions. It is insightful to examine continental and transcontinental sourcing separately to understand future global sourcing trends. While a decreasing trend is already evident in European sourcing, there is a lack of investigation into the nature and effects of transcontinental sourcing. 
This research, in its empirical content, relies on 21 semi-structured interviews conducted during the crisis with European industrial companies engaged in transcontinental sourcing. We run two sets of inquiries: First, directly asking about purchaser's expectations towards the impact of Corona on the trend towards transcontinental sourcing. Second, inquiring about their motives and challenges regarding transcontinental sourcing. With the latter, we can analyse the potential impact in more detail regarding the individual motives of transcontinental sourcing.

This paper contributes twofold to literature and practice: First, we contribute to the increasing crisis literature by offering a novel and well-grounded perspective on developing global sourcing in and after the pandemic. We concentrated on motives, challenges and solutions of transcontinental sourcing to gain insight into global sourcing trends. Second, introducing the split between continental and transcontinental sourcing, this paper contributes to global sourcing literature by pointing out that global sourcing might not be one phenomenon but consist of at least two, continental and transcontinental sourcing. This is a theory contribution worth discussing in the future, independently from the final evaluation of the COVID-19 crisis. It might be an important contribution of substantial theoretical and practical relevance to highlighting the differences between the two forms of sourcing as part of global sourcing.

The next section will introduce global sourcing challenges and argue for distinguishing between continental and transcontinental sourcing. Then, we focus on the qualitative study on transcontinental sourcing and COVID's implications before analysis and conclusion can be drawn.

\section{Theory: global sourcing as a conglomerate of continental and trans- continental sourcing}

2.1 Global sourcing: Profiting from international purchasing

Global sourcing is explained as sourcing goods from suppliers internationally (Bohnenkamp et al., 2020; Schiele et al., 2011), being defined as seizing "purchasing potential on a worldwide level" (Arnold, 1989, p. 26). Companies choose global sourcing to remain competitive in an increasingly interconnected world (Weigel and Ruecker, 2017).

Advantages mentioned in literature are numerous, including the creation of cost savings (Alguire et al., 1994; Monczka and Morgan, 2000; Tsai et al., 2008; Weigel and Ruecker, 2017), the access to better quality and the introduction of competition for the domestic supply base (Trent and Monczka, 2003b), or access to new technologies and markets (Ettlie and Sethuraman, 2002). Companies in many industries abandoned their local-for-local focus and started to pursue global sourcing approaches, shifting attention towards low-cost countries (Christopher et al., 2011; Monczka and Morgan, 2000).

Next to the benefits involved, however, global sourcing can also entail several obstacles: Global sourcing increases the lengths of supply networks and makes them more complex by involving more partners (Christopher and Peck, 2004). For this reason, global supply chains are far more difficult to handle than local ones (MacCarthy and Atthirawong, 2003). Several other challenges arise with sourcing on a global scale: Cho and Kang (2001) distinguish between four factors, including regulations (such as quotas and trade restrictions), logistics and transport delays, cultural differences in terms of language and business practices and exchange rate instability. Others add that predicted increases in production efficiency might be offset by lower quality (Axelsson et al., 2005; Trent and Monczka, 2005). In recent years, a new set of challenges has been added, evolving around CSR (corporate social responsibility), respectively, ESG (environment, social and governance) (Rühmkorf, 2017) (Jiang et al., 2019)
Turning point in stopping global sourcing 
JGOSS

15,2

222

and the consequences of the new compliance legislation asking for more supply chain transparency and responsibility (Mazahir and Ardestani-Jaafari, 2020).

Empirically, in recent times, we can distinguish between three phases of global trade development: in the first phase (1974-2000), we see growth of $8.5 \%$ p.a., followed by a phase of accelerated international trade expansion (2001-2011) of about $16.7 \%$ p.a. Since then (2012-2019) the growth has been stagnating at an average of $0.3 \%$ p.a. (WTO, 2021). This stagnation is also confirmed when calculating the elasticities in the last decade: world trade $(+2.4 \%$ p.a.) followed almost exactly the expansion of world GDP $(+2.6 \%$ p.a.), i.e. it presented an elasticity of 0.92 (Figure 1).

Most recently, challenges to global sourcing in the context of the COVID crisis have been added, which may make this sourcing strategy appear less attractive. For instance, Baldwin describes the influence of COVID-19 on worldwide trade and recognises that COVID-19 bears the risk to permanently damage the trading system. He proposes dual sourcing to reduce the dependence on China (Baldwin and Tomiura, 2020). Gereffi shows the impact of the COVID-19 pandemic on global supply chains. The study investigates the face mask value chains in the United States, exposing government intervention as a factor leading to market failure (Gereffi, 2020). Such government interventions could well be a factor supply managers might have to monitor more closely in the future. Behavioural changes may result from the experience with supply chain interruptions due to the crisis (Sarkis et al., 2020). Besides, there are investigations concerning the future of supply chains after the pandemic. For example, Buatois identifies a change to higher flexibility and multi-level sourcing (Buatois and Cordon, 2020), while Rashad proposes a framework regarding supply chain strategies to improve the reactions to challenges in global sourcing. Using lean, agility and "liability" as supply chain strategies, Rashad presents suggestions to solve challenges like the COVID-19 pandemic by increasing flexibility (Rashad and Nedelko, 2020).

All these elaborations share the notion of just one type of global sourcing, i.e. they neglect the difference between slightly international and considerably global sourcing, such as buying from suppliers located in the neighbouring country using the same currency or from those in another continent and time zone. As the next section shows, however, there seems to

Figure 1. Phases of global sourcing

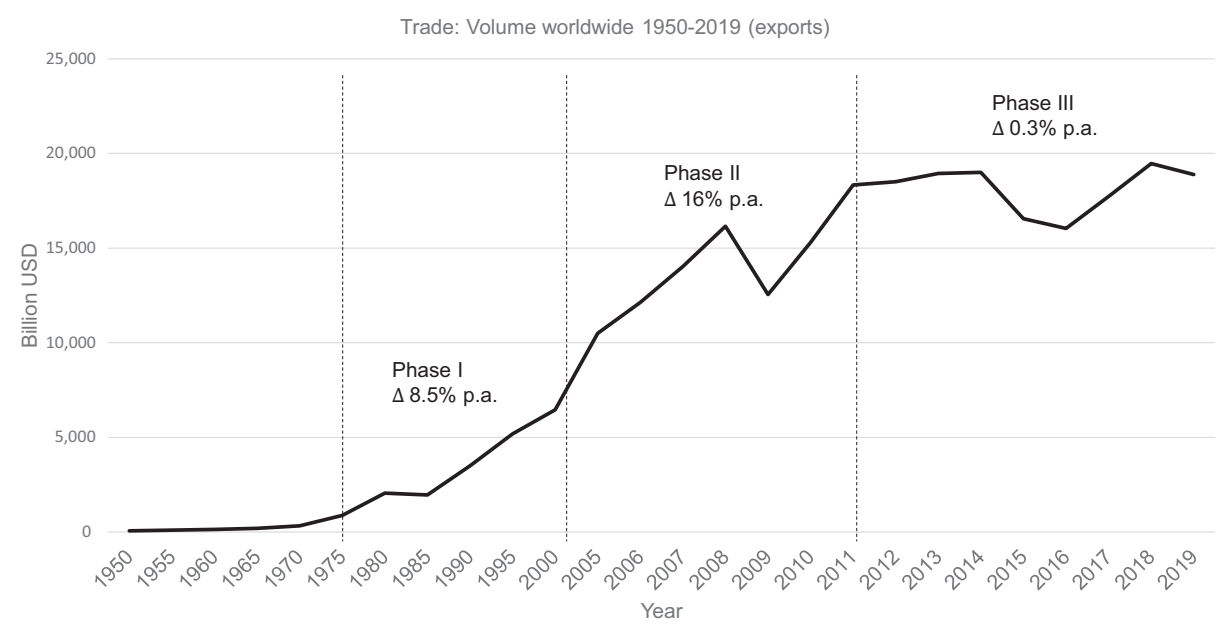

Source: UNCTAD, WTO; 1950 to 2019 
be a need to differentiate global sourcing further into continental and transcontinental sourcing.

\subsection{European sourcing as an intra-continental form of global sourcing}

Generally speaking, there are differences regarding the distance in global sourcing, asking to differentiate between continental and transcontinental sourcing (Schiele et al., 2020): With transcontinental sourcing, considerable time-zone differences apply, cultural aspects tend to be more pronounced, and -particularly from a European perspective - legal framework differences are present. In Europe, continental sourcing means joining the same legal area and currency or a limited currency fluctuation. At least in the European case and regarding the quest for understanding the trend towards global sourcing, there are empirical differences: In the past decades, transcontinental sourcing gained relative importance on the expenses of continental sourcing. Since our perspective is a European one, in that case, continental sourcing means "European sourcing", operationalised as intra-EU trade. However, it can be assumed that similar phenomena might apply to other trade areas, such as South-East Asia or South America (Mercosul).

Global sourcing consists of European sourcing and transcontinental sourcing, while transcontinental or "remote" sourcing means that suppliers are situated on other continents (Schiele et al., 2020). Therefore, transcontinental sourcing is a special part of global sourcing, whereas European sourcing is another part of global sourcing, a form of continental sourcing (Figure 2).

To differentiate these two forms of global sourcing and motivate a separate perspective, it is worth investigating the development of intra-European trade (i.e. continental sourcing). According to a variety of different calculations, the introduction of the euro has been found to have contributed to additional growth in trade in the magnitude of $4 \%-16 \%$. For instance, Camarero et al. (2013) estimate the adoption of the euro to have increased exports between EMU (Economic and monetary union) members by 13\%-16\%. Kunroo et al. (2016) estimate the effect of the euro introduction on increasing inter-European trade at about $14 \%$, with a $6 \%$ higher effect if both countries joined the euro. Furthermore, the introduction of the Schengen agreement was found to further boost trade by its member states by another $2 \%-3 \%$ on average, on top of the EU's general trade effects. This effect was even stronger for services than for goods (Felbermayr et al., 2018). Expressed in a share of GDP (Gross domestic product), intra-EU exports have grown from a mere $6 \%$ to $20 \%$ between 1960 and 2000 (growth phase). Also, new EU member countries from Central and Eastern Europe (i.e. former transition economies) have, on average, seen their export-GDP ratio double in size between 1990 and 2013 (Vrh, 2017). However, since then, it entered into a stagnation phase, oscillating around that value (Podkaminer, 2016). For instance, with export effects through

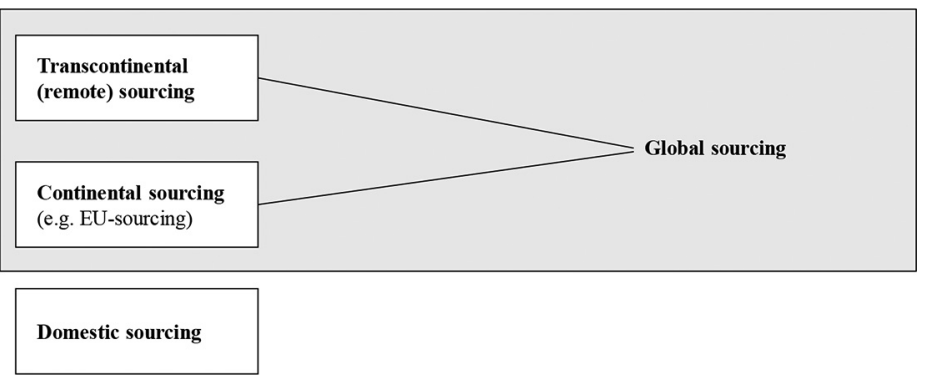

Turning point in stopping global sourcing

223

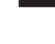


JGOSS

15,2

224

euro adoption, Cieślik et al. (2012) conclude: "In the case of exports to the EMU member countries, this effect lasts only for two years and in the case of total exports for 3 years". Hence, the above measures, like common market, common currency and common border, seem to have more of a staircase effect than a continuously rising ramp, which may explain the slowing down of the expansion.

Traditionally, EU member states as a whole have traded more goods with other member states than with countries outside the EU, except the UK and Cyprus (Eurostat, 2021). However, current trade statistics show that in the past 15 years, this value has been in decline (Table 1). This means it displays the relative value of trade within the EU (in this calculation still including the UK) compared to trade with partners outside the EU. Negative values mean that Europe has lost importance for the firms in the respective country. For instance, the first line shows that, Belgium saw a reduction of $4.6 \%$ in the share of their EUtrade compared to external trade. On average, while in $2003,69.1 \%$ of trade was within Europe, in 2019, the value was only $63.8 \%$, more than $5.3 \%$ lower. In the case of an overwhelming amount of products with almost all countries (except for Malta, Romania and Bulgaria), we observe a relative decline of intra-European trade, reflecting that relatively less European sourcing is taking place (Eurostat, 2021).

A particularly extreme case is Britain, whose intra-European trade fell from $61.4 \%$ to $46.3 \%$. While back in 2003, Britain was still trading much more than half of its international volume to other EU countries, in 2019, this value had decreased to less than half. This means that Europe lost importance to Britain (which might actually have had an influence on Brexit, i.e. that country's decision to leave the EU and the common market). We observe a very relevant change in trade patterns here, with transcontinental trade gaining importance and continental sourcing losing ground. This pattern was seen with almost all European countries, and, interestingly, even more so to those using the common currency (non-euro countries saw a decline in $3.6 \%$ on average, while the relevance of inter-EU-trade fell by

Table 1.

Decline of intracontinental trade

\begin{tabular}{lclc}
\hline Country & $\begin{array}{c}\text { Intra-EU trade change all } \\
\text { products: } 2003-2019(\%)\end{array}$ & Country & $\begin{array}{r}\text { Intra-EU trade change all } \\
\text { products: 2003-2019(\%) }\end{array}$ \\
\hline Belgium & -4.6 & Lithuania & -4.0 \\
Bulgaria & 2.7 & Luxembourg & -5.2 \\
Czechia & -4.0 & Hungary & -3.4 \\
Denmark & -11.6 & Malta & 6.8 \\
Germany & -6.8 & Netherlands & -7.0 \\
Estonia & -11.9 & Austria & -5.7 \\
Ireland & -15.0 & Poland & -2.3 \\
Greece & -10.9 & Portugal & -4.3 \\
Spain & -8.8 & Romania & 0.9 \\
France & -8.6 & Slovenia & -3.6 \\
Croatia & -0.6 & Slovakia & -1.6 \\
Italy & -6.8 & Finland & -1.5 \\
Cyprus & -14.8 & Sweden & -13.0 \\
Latvia & -12.2 & United Kingdom & -5.3 \\
Average EURO & -6.7 & European Union -28 & \\
countries & -3.6 & & \\
Average Non- & & & \\
EURO & & & \\
countries & & & \\
Source: Data from Eurostat, 2021 & & \\
\hline
\end{tabular}


$6.7 \%$ in the common currency area). Hence, at least in the European perspective and in the last period, global sourcing seems to have strongly been propelled more by transcontinental sourcing, not the nearer type of continental sourcing.

The observation of a weakening intra-EU-trade (continental sourcing) as part of global sourcing illustrates the necessity to investigate transcontinental sourcing as another important part of global sourcing, if we want to identify trends and effects of the current pandemic. There is an apparent empirical difference between the two forms of global sourcing, as one is declining and the other form increasing. If COVID-19 was particularly hitting transcontinental sourcing activities, we could expect an overall decline in international trade, if it was not, there would be less reason to challenge the continuation of the trend towards global sourcing. To understand the nature of transcontinental sourcing and then better assess the potential impact of the pandemic, we conducted 21 semistructured interviews with a sample of companies that are particularly exposed, dealing with a high share of remote and transcontinental suppliers.

\section{Empirical analysis}

\subsection{Method: semi-structured interviews analysed using the Gioia method}

We conducted 21 interviews from March to June 2020 and coded these interviews with the Software Atlas.ti. Semi-structured interviews collect data in a versatile and flexible way (Kallio et al., 2016). Within semi-structured interviews, predetermined questions are prepared while the interviewed person gives explanations and examples (Aksu, 2009; Doody and Noonan, 2013). The distribution of the interviewees regarding their industry sector is as follows: electronics (6), automotive (3), metalworking (3), health (2) and recreation, construction, IT, logistics, publishing, retail and textile (1 each). Most of the interviewed companies belong to the engineering and automotive sector in Central Europe. The sampling criterion for these companies was their high share of transcontinental sourcing activities; purely domestic firms, or those with almost no remote sourcing experience were not involved.

To analyse the gathered data and statements of the interviews, we applied the method of Gioia. According to Gioia et al., qualitative data are structured by creating clusters of the answers. Based on semi-structured interviews, Gioia's method inductively generates a concept development and includes three phases to receive structured data (Gioia et al., 2013). The first phase consists of building first-order categories by finding redundancies and similarities in the answers given by the interviewees. This step creates a more feasible amount of categories with labels and descriptions (Gioia et al., 2013). In the second phase, these categories receive a deeper structure by relating them to themes on a theoretical level. During the last phase, second-order themes are developed into second-order aggregated dimensions.

By using Gioia's method, motives, challenges and corresponding solutions were identified. At the same time, respondents were directly asked to discuss expectations towards the trend of transcontinental sourcing. We structured many codes (over 2,500 coding points) and gained a data structure in this context.

\subsection{Findings: expected impact, motives, challenges and solutions}

Concerning the future of transcontinental sourcing, we developed a separate data model. 1st order concepts include codes derived from the semi-structured interviews. As a first step, redundancies and similarities generate groups based on similar codes. Figure 3 shows firstorder concepts such as "remains the same", "trend to localise", "prefer remote" and "outsourcing because of costs". Additionally, first-order concepts are grouped into second- 
JGOSS 15,2 1st order concepts (Codes)

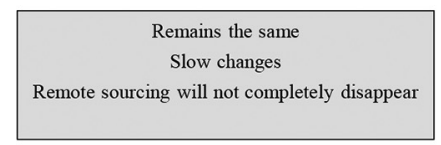

2nd order themes

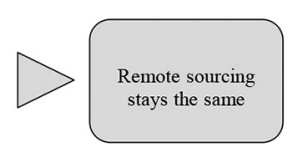

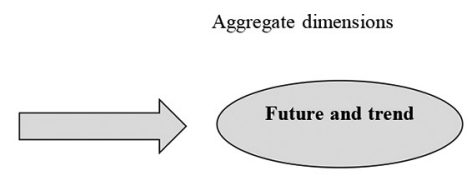

\section{6}
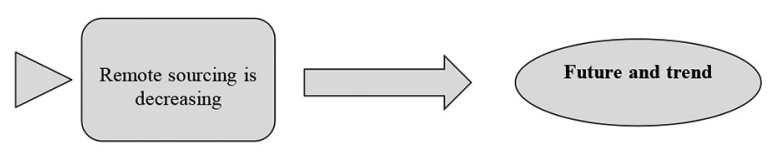

Figure 3.

Result of the data structure according to Gioia: Trends and future of transcontinental sourcing.
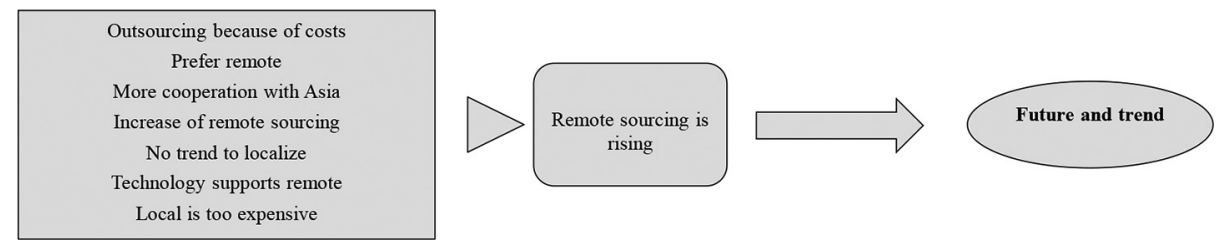

order themes on a theoretical level, according to the data structure in Figure 3. Hence, "remote sourcing stays the same", "remote sourcing is decreasing" and "remote sourcing is rising" are outlined as second-order themes. This phase results in the dimension "future and trend" of transcontinental sourcing by aggregating these mentioned themes.

Counting the codes, we identify 12 references expressing the opinion that sourcing will stay the same or change slowly after the COVID crisis. Nine references expressed an expectation of decline, mainly due to increasing local sourcing, also induced by increasing costs in former low-cost countries, such as China, and 18 that can be associated with the expectation of continuous growth in transcontinental sourcing. Therefore, it can be concluded that while respondents see a partial pressure on reducing transcontinental sourcing, there seems to be a slight emphasis on the idea of a trend continuation, with remote sourcing continuing to be an attractive strategic alternative. At least, it can be concluded that a clear trend for reversal cannot be found in the data.

To validate this finding, in the next step, we dissected the motives, challenges and solutions firms applied with transcontinental sourcing so that, eventually, these can be discussed in terms of how they may change after the pandemic (Figure 4).

- Motives: According to our interviews, costs and margins are the main reason for transcontinental sourcing, similar to global sourcing motives in general. Companies need to consider their production systems globally to lower their costs and gain a competitive advantage. Attractive purchasing and manufacturing costs, like in the Far East, pose an advantage for the interviewees.

- Additionally, technology and innovation are essential motives mentioned by the interview partners. Quality and supplier's know-how underline the exclusivity and importance of transcontinental partners. Besides, availability, capacity and response time represent important components concerning motives. Local customers on-site and possible alternatives within clusters motivate purchasing departments to source on other continents. Another point, which can be identified as 
1st order concepts (Codes)

Costs and margin
Exclusivity of supplier: Quality, Technology/
Innovation, Raw materials,
Opportunities: Availability/ capacity, speed of
reaction, alternatives, local customers on site,
strong cluster

Interaction: Culture, communication, language, distance, availability, accessibility, moral hazard

Operative indicators: Delivery times, reliability, crises, quality, total costs (Transport, returns)

Strategic indicators: Loss of image
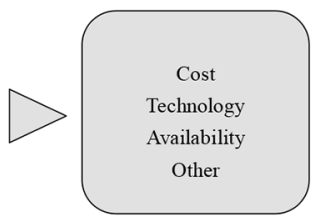

Aggregate dimensions
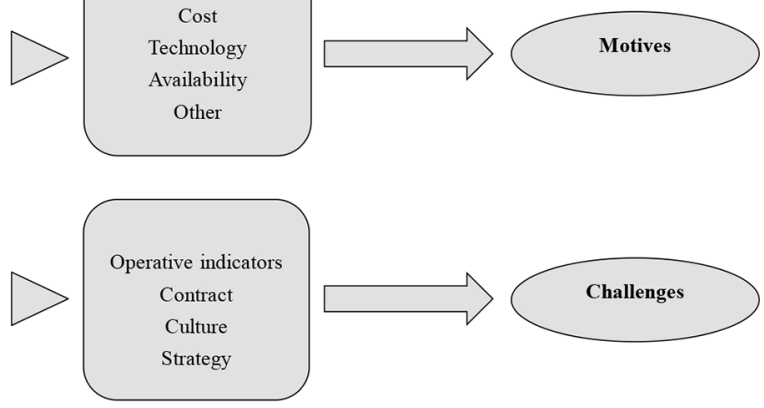

Turning point in stopping global sourcing

227
Communication: Fairs, supplier days, meetings, visits on site, direct contact, contact persons, presence on site

Visibility: Monitoring, certificates, transparency of supply chain, KPIs

Connections: Long term relationship, networking, special contracts

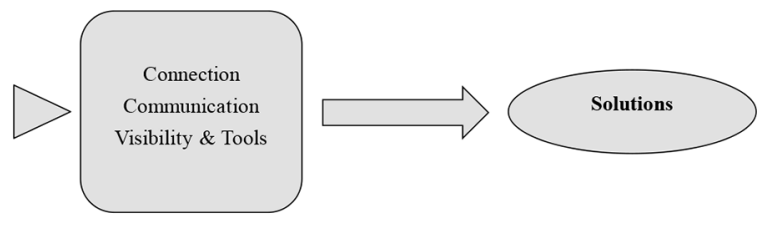

Figure 4.

Result of the data structure according to

Gioia

a motive for transcontinental sourcing, includes availability of raw materials on other continents.

- Challenges: Considering the challenges of transcontinental sourcing, interaction problems like culture, communication and language appear. These challenges also include distance, difficult accessibility and availability. In some cases, moral hazard due to information asymmetries occurs. Apart from strategic indicators like a loss of image, if the origin of the supplies become apparent, and operative indicators are named in the context of challenges for transcontinental sourcing. For example, in the COVID-19 pandemic, production plant shutdowns and delivery failures occurred.

- Solutions: To solve the challenges mentioned above, interviewed companies refer to concepts like improved communication, visibility and strong connections. Longterm relationships, special contracts and intensive networking support the connections between suppliers and buyers and reduce the risks of transcontinental sourcing. Regarding visibility, different certificates, the transparency of supply chains and key performance indicators (KPIs) for monitoring purpose is used to increase a supplier's visibility. With fairs, supplier days and presence on-site, the communication between buyers and suppliers is improved. Contact persons and meetings supplement possible solutions.

Based on identifying the motives, challenges and applied solutions, particularly referring to the firm's engagement in transcontinental sourcing, in the last section, we can discuss assumed influences on the continuation of transcontinental sourcing and, hence, global persistence sourcing after the pandemic. 
JGOSS

15,2

228

\section{Discussion: a weak tendency to continuation of the transcontinental sourcing trend}

Using this data structure and identifying motives, challenges and solutions, the impact of COVID-19 on each $2^{\text {nd }}$ order theme can now be examined (Table 2). While the findings reflect the direct perceptions of the responding firms, this part is our reflection. The illustration structurally summarises the reasoning so that the reader might also form an opinion of their own applying the scheme.

While there is a decline of intra-EU-trade, at least from a medium-term perspective, the pandemic decreases European competitiveness and increases cost advantages of the Asian region. Even more, the economic consequences of the shutdowns in Europe and relatively light effects in Asia may create bankruptcies of suppliers within the EU. Furthermore, loans to cover the crisis now are taxes of the future, reducing the competitiveness of the taxpaying European suppliers. Such additional burdens can generate further cost advantages for suppliers in Asia and increase transcontinental sourcing. Therefore, in the above table, we assigned this aspect to an +1 , i.e. a factor supporting the increase in transcontinental sourcing.

The following statements underline this:

At the moment, the reason for us to go there are the lower costs.

Another important aspect is the risk vulnerability of operative challenges in transcontinental sourcing, which became evident during the COVID-19 pandemic. For example, one automotive company mentioned:

At the end of February [2020], beginning of March, we had extreme problems getting everything from China to Germany.

However, the risk vulnerability may be compensated by better industry 4.0 tools like blockchain.

Regarding strategic challenges, the Chinese markets are saturated, while European customers have become less attractive in the pandemic. Hence, European companies lose their preferred customer status, which is essential for transcontinental sourcing and global sourcing (Schiele et al., 2012; Claus Steinle and Holger Schiele, 2008). This phenomenon was expressed several times in the interviews, as purchasers engaged with transcontinental suppliers, namely from China, observed a decline in their attractiveness due to an increase in a strong domestic customer base for these suppliers. This point is supported by the following statement of one interviewee from the automotive industry:

The biggest advantage that existed 10 years ago when that all the whole drive start to go to China costs is slowly disappearing. At that time, there was no local demand in China. The local demand has changed in China. So the whole picture, the whole global environment has changed.

In this context, the demand interruptions due to the COVID-19 crisis could have a strong reinforcing impact, further reducing the attractiveness of transcontinental customers and, as such, forcing them to rely more on domestic or continental sources.

A stronger connection to suppliers represents a solution for the challenges of transcontinental sourcing.

We expect that if the relationship with our contact person is good enough, he will fight for us to act in our interest. 


\begin{tabular}{|c|c|c|c|c|}
\hline 2nd order codes & Aggregate & Impact COVID-19 pandemic & $\begin{array}{c}-1=\text { Decrease } \\
+1=\text { Increase }\end{array}$ & I urning point \\
\hline Cost & Motives & $\begin{array}{l}\text { More recession in the EU, loans } \\
\text { (taxes of the future), a decrease } \\
\text { in European competitiveness } \rightarrow \\
\text { Cost advantages Asia }\end{array}$ & 1 & sourcing \\
\hline \multirow{2}{*}{$\begin{array}{l}\text { Technology/quality } \\
\text { Availability }\end{array}$} & \multirow{2}{*}{$\begin{array}{l}\text { Motives } \\
\text { Motives }\end{array}$} & No immediate impact & \multirow{2}{*}{$\begin{array}{l}0 \\
1\end{array}$} & \\
\hline & & $\begin{array}{l}\text { More recession/less growth in } \\
\text { EU, bankruptcies suppliers } \rightarrow \\
\text { Availability advantages Asia }\end{array}$ & & \\
\hline Operative/risk & Challenges & $\begin{array}{l}\text { Risk vulnerability became } \\
\text { evident, but better I } 4.0 \text { tools such } \\
\text { as blockchain may compensate }\end{array}$ & 0 & \\
\hline Contract & Challenges & No immediate impact from C19 & 0 & \\
\hline Communication/culture & Challenges & No immediate impact & 0 & \\
\hline Strategic & Challenges & $\begin{array}{l}\text { China more auto-sufficient, } \\
\text { European customers less } \\
\text { attractive }\end{array}$ & -1 & \\
\hline Connection & Solutions & $\begin{array}{l}\text { More difficult to bond with } \\
\text { remote suppliers due to C19 } \\
\text { experience }\end{array}$ & -1 & \\
\hline Communication & Solutions & $\begin{array}{l}\text { Industry } 4.0 \text { technologies may } \\
\text { help }\end{array}$ & 1 & $\begin{array}{r}\text { Table } 2 . \\
\text { Impact of COVID-19 }\end{array}$ \\
\hline \multirow[t]{2}{*}{ Visibility/Tools } & Solutions & No immediate impact & 0 & $\begin{array}{r}\text { on decrease or } \\
\text { increase of }\end{array}$ \\
\hline & Conclusion & $\begin{array}{l}\text { Continuation, a slight increase of } \\
\text { remote sourcing expected }\end{array}$ & 1 & $\begin{array}{r}\text { transcontinental } \\
\text { sourcing }\end{array}$ \\
\hline
\end{tabular}

Due to the current pandemic, a strong bond with remote suppliers is more difficult to establish, making it harder to contact such vendors. This may result in a decrease in transcontinental sourcing. On the other hand, industry 4.0 technologies support better communication between buyers and suppliers; likewise, videoconferencing experiences its breakthrough.

It [industry 4.0] makes the communication just a lot easier. Especially for us when we talk to

Chinese people that struggle with the English language.

Focusing on investigated industry sectors, respondents from companies in the automotive, textile and health-care sector believed that the importance of transcontinental sourcing would remain the same. Besides, two firms in the metalworking industry expect no change in this trend. On the other hand, the manufacturing and engineering industry deviated from this and expressed the expectation of an increase in transcontinental sourcing. In contrast, one interviewed company in the logistics sector seems to prefer local sourcing in the future.

Regarding the conducted interviews and the interpretation of the motives, it might be fair to conclude that the current COVID-19 pandemic does not appear as a turning point against transcontinental sourcing. However, it must be advised that the sample size of this study can only justify propositions, which must be verified. Concerning the questions about their future expectations on transcontinental sourcing, the manufacturing and engineering 
JGOSS

15,2

industry stated that the importance of this extreme form of global sourcing is likely to increase in the future. However, the majority of the remaining industry experts anticipate no change in their sourcing strategies.

\section{Conclusion: continuation of transcontinental sourcing and need for a more differentiated understanding of global sourcing}

In this research, we asked if the COVID-19 pandemic could be a turning point leading to a decline in international trade and possibly requesting purchasers to reconsider their sourcing strategies. It was argued that we benefit from distinguishing between intracontinental sourcing and trans-continental sourcing, both jointly composing "global sourcing". Transcontinental sourcing is the main driver for global sourcing, at least from a European perspective. A decline in the relative importance of continental European sourcing in the last decades coincided with an increase in the importance of transcontinental sourcing. Hence, to estimate the future of global sourcing, we focused on transcontinental sourcing, collecting the opinion of a sample of purchasers engaged in transcontinental sourcing. Based on the analysis of their specific motives for transcontinental sourcing, it became clear that factors supportive as well as detrimental to transcontinental sourcing are about outweighing each other. For example, costs are strong motives to choose transcontinental suppliers, whereas operative challenges like quality issues and delivery failures represent obstacles.

Concerning the research question on the pandemic's impact on global sourcing, this research leads to the conclusion that we did not find evidence for a trend reversal; in the words of a respondent:

Transcontinental sourcing does not decrease. There will be a similar situation if cost aspects still play an important role.

\subsection{Managerial implications: continuation of transcontinental sourcing, but consideration of attractiveness factors}

From a managerial perspective, this research implies that firms may not want to completely reverse their sourcing strategies to reflect the effects of the pandemic. It has been argued that the underlying mechanisms remain the same, for instance single source strategies enabling pooling discounts. Locational choices continue to be based on cost, technology/ quality and availability considerations. The latter aspect has been less emphasised in previous research, but represents a very relevant practical decision criterion surfacing in our interviews. Firms may use Table 2 as a checklist to determine their business partner choice.

A remarkable finding alerts managers to pay more attention to their company's attractiveness. As discussed with the case of China, several of our study participants perceived a decline in their attractiveness for Chinese suppliers, which may now enjoy a larger local customer base. Here, the COVID-19 pandemic might indeed have an influence in further reducing the attractiveness of customers located far away. However, research has not focussed very much on understanding international customer attractiveness factors, which might be a rewarding path for future research.

\subsection{Research implications: differentiating between continental and transcontinental sourcing and understanding intra-EU trade development}

It can be concluded that this research contributes to the rapidly emerging COVID-19 pandemic literature and global sourcing/sourcing strategy literature in general. This is arguably the first study to explicitly focus on the difference between continental 
and transcontinental sourcing. Our findings suggest a rewarding path for future research to establish this difference, as there is an apparent empirical phenomenon. Future research may benefit from testing the effect of continental vs. transcontinental location of business partners. Considering the typical research domain development as consisting of the identification of a phenomenon, the identification of its antecedents and consequences, deriving actionable implications and then the analysis of contingencies (Schiele, 2020), this paper has exposed the phenomenon, showing a difference between continental and transcontinental sourcing. Future research may want to understand the antecedents of this phenomenon. Which factors can explain the observation? Are they generally true? And which are the contingencies, i.e. is it a European phenomenon, does it cover other trade blocks, as well, or are we observing an even more general "stuck in the middle" phenomenon, successful buyer-supplier relations being either domestic or accessing low costs or high technology on a very remote level, but not something in between?

Second, by combining secondary data analysis in a time perspective with in-depth interviews, this research unveils a previously overlooked phenomenon, the relative decline of continental and the rise of transcontinental sourcing in Europe. By doing so, findings also challenge an implicit assumption of much of the global sourcing literature, which does only differentiate between domestic and global sourcing, in the maximum sometimes emphasising "low-cost country sourcing", but neglecting the medium range sourcing. However, we also need to understand why we have seen a shift in Europe benefiting transcontinental sourcing on the expenses of European sourcing and if this trend is also present in other areas. From a cultural, distance and legal framework perspective, the opposite trend favouring more close sourcing relationships would have been expected. As such, this finding is counter-intuitive, even more that a common currency correlated stronger with a loss of importance of these suppliers. An important question would be to understand the theoretical reasons for this shift towards remote, transcontinental sourcing, allowing generalising findings.

\subsection{Limitations: potential government interventions and length of crisis}

However, there are limitations to our study and the conducted interviews. Our limited number of interview partners share a European perspective and have been collected at a special moment during the first phase of the Corona pandemic (March-June 2020). Then, a brief end to the calamities was expected. Challenges with allocation in the recovery phase, possibly with a stronger emphasis on issues with remote sourcing, might eventually lead to different conclusions.

It should be added that the results of our research are no prognoses, but conditional to governmental actions, which could be unexpected. For instance, restrictions in international trade could be applied or the increasing supply chain due diligence requirements may turn it too risky to source from certain remote countries. As for now, restrictions in transcontinental sourcing due to corporate social responsibility issues have not been reported.

Finally, the study includes a high share of Central European manufacturing firms whose transcontinental focus lies on China. Hence, it should be verified - on a larger empirical base - if the conclusion of a continuation of the trend towards transcontinental sourcing is not actually a trend towards the continuation of Sino-European business, only.
Turning point in stopping global sourcing

231 


\section{JGOSS \\ 15,2}

\section{References}

Aksu, H.H. (2009), "Questionnaries and interviews in educational researches", Journal of Graduate School of Social Sciences, Vol. 13 No. 1, pp. 201-216.

Alajääskö, P. (2009), "International sourcing in Europe", EUROSTAT Statistics in Focus, Vol. 2, p. 2009.

Alguire, M.S., Frear, C.R. and Metcalf, L.E. (1994), "An examination of the determinants of global sourcing strategy", Journal of Business and Industrial Marketing, Vol. 9 No. 2, pp. 62-74, doi: 10.1108/08858629410059843.

Altuzarra, A., Bustillo, R. and Rodríguez, C. (2020), "Is world trade slowing down? New evidence on trade-income elasticity”, Panoeconomicus, No. 00, pp. 13-13, doi: 10.2298/PAN190722013A.

Arnold, U. (1989), "Global sourcing: an indispensable element in worldwide competition”, Management International Review, Vol. 29 No. 4, pp. 14-28, doi: 10.2307/40227944.

Auer, R., Borio, C.E. and Filardo, A.J. (2017), "The globalisation of inflation: the growing importance of global value chains", p. 6387 CESifo Working Paper.

Axelsson, B., Rozemeijer, F. and Wynstra, J. (2005), Developing Sourcing Capabilities: Creating Strategic Change in Purchasing and Supply Management, Chichester: Wiley.

Baldwin, R. and Tomiura, E. (2020), "Thinking ahead about the trade impact of COVID-19", In Economics in the Time of COVID-19, pp. 59-73, available at: https://innowin.ir/api/media/ BQACAgQAAxOCPPk4JwACHxZeusXcwX.pdf\#page=66

Bengtsson, L., Von Haartman, R. and Dabhilkar, M. (2009), "Low-cost versus innovation: contrasting outsourcing and integration strategies in manufacturing", Creativity and Innovation Management, Vol. 18 No. 1, pp. 35-47.

Bohnenkamp, T., Schiele, H. and Visser, M.D. (2020), "Replacing global sourcing with deep localisation: the role of social capital in building local supply chains", International Journal of Procurement Management, Vol. 13 No. 1, pp. 83-111, doi: 10.1504/IJPM.2020.105200.

Bozarth, C., Handfield, R. and Das, A. (1998), "Stages of global sourcing strategy evolution: an exploratory study", Journal of Operations Management, Vol. 16 Nos 2/3, pp. 241-255, doi: 10.1016/S0272-6963(97)00040-5.

Buatois, E. and Cordon, C. (2020), "A post COVID-19 outlook: the future of the supply chain”, IMD Tomorrow's Challenges, pp. 1-4, available at: www.imd.org/contentassets/c46625dde711402a 8b7a4f46e75c1c84/tc046-20-file-.pdf

Camarero, M., Gómez, E. and Tamarit, C. (2013), "EMU and trade revisited: long-run evidence using gravity equations", The World Economy, Vol. 36 No. 9, pp. 1146-1164.

Cho, J. and Kang, J. (2001), "Benefits and challenges of global sourcing: perceptions of US apparel retail firms", International Marketing Review, Vol. 18 No. 5, pp. 542-561, doi: 10.1108/EUM0000 000006045 .

Christopher, M. and Peck, H. (2004), "Building the resilient supply chain", The International Journal of Logistics Management, Vol. 15 No. 2, pp. 1-14.

Christopher, M., Mena, C., Khan, O. and Yurt, O. (2011), “Approaches to managing global sourcing risk", Supply Chain Management: An International Journal, Vol. 16 No. 2, pp. 67-81.

Cieślik, A., Michałek, J.J. and Mycielski, J. (2012), "Measuring the trade effects of the euro in Central and Eastern Europe", The Journal of International Trade and Economic Development, Vol. 21 No. 1, pp. 25-49.

Doody, O. and Noonan, M. (2013), "Preparing and conducting interviews to collect data", Nurse Researcher, Vol. 20 No. 5, pp. 29-32, doi: 10.7748/nr2013.05.20.5.28.e327.

Ettlie, J.E. and Sethuraman, K. (2002), "Locus of supply and global manufacturing”, International Journal of Operations and Production Management, Vol. 22 No. 3, pp. 349-370, doi: 10.1108/ 01443570210417632. 
Eurostat (2021), "Intra and extra-EU trade by member state and by product group", available at: https:// appsso.eurostat.ec.europa.eu/nui/show.do?dataset=ext_lt_intratrd\&lang=en

Felbermayr, G., Gröschl, J. and Steinwachs, T. (2018), "The trade effects of border controls: Evidence from the European Schengen agreement”, JCMS: Journal of Common Market Studies, Vol. 56 No. 2, pp. 335-351.

Gereffi, G. (2020), "What does the COVID-19 pandemic teach us about global value chains? The case of medical supplies", Journal of International Business Policy, Vol. 3 No. 3, pp. 287-301, doi: 10.1057/ s42214-020-00062-w.

Gioia, D.A., Corley, K.G. and Hamilton, A.L. (2013), "Seeking qualitative rigor in inductive research: Notes on the gioia methodology", Organizational Research Methods, Vol. 16 No. 1, pp. 15-31, doi: $10.1177 / 1094428112452151$.

Giunipero, L.C., Bittner, S., Shanks, I. and Cho, M.H. (2019), "Analyzing the sourcing literature: over two decades of research", Journal of Purchasing and Supply Management, Vol. 25 No. 5, p. 100521, doi: 10.1016/j.pursup.2018.11.001.

Jiang, Y., Jia, F., Blome, C. and Chen, L. (2019), "Achieving sustainability in global sourcing: towards a conceptual framework", Supply Chain Management: An International Journal, Vol. 25 No. 1, pp. 35-60, doi: 10.1108/SCM-12-2018-0448.

Kallio, H., Pietilä, A.M., Johnson, M. and Kangasniemi, M. (2016), "Systematic methodological review: developing a framework for a qualitative semi-structured interview guide", Journal of Advanced Nursing, Vol. 72 No. 12, pp. 2954-2965, doi: 10.1111/jan.13031.

Kinkel, S. (2012), "Trends in production relocation and backshoring activities", International Journal of Operations and Production Management, Vol. 32 No. 6, pp. 696-720, doi: 10.1108/ 01443571211230934.

Kunroo, M.H., Sofi, I.A. and Azad, N.A. (2016), "Trade implications of the euro in EMU countries: a panel gravity analysis", Empirica, Vol. 43 No. 2, pp. 391-413.

MacCarthy, B.L. and Atthirawong, W. (2003), "Factors affecting location decisions in international operations-a delphi study", International Journal of Operations and Production Management, Vol. 23 No. 7, pp. 794-818, doi: 10.1108/01443570310481568.

Mazahir, S. and Ardestani-Jaafari, A. (2020), "Robust global sourcing under compliance legislation", European Journal of Operational Research, Vol. 284 No. 1, pp. 152-163, doi: 10.1016/j. ejor.2019.12.017.

Monczka, R.M. and Morgan, J.P. (2000), “Outsourcing: key to many competitive battles”, Purchasing, Vol. 129 No. 3, pp. 85-91.

Podkaminer, L. (2016), "Economic disintegration of the European union: not unavoidable, but probable", Acta Oeconomica, Vol. 66 No. s1, pp. 49-60.

Quintens, L., Pauwels, P. and Matthyssens, P. (2006), "Global purchasing: state of the art and research directions”, Journal of Purchasing and Supply Management, Vol. 12 No. 4, pp. 170-181, doi: 10.1016/j.pursup.2006.10.006.

Rashad, W. and Nedelko, Z. (2020), "Global sourcing strategies: a framework for lean, agile, and leagile”, Sustainability, Vol. 12 No. 17, p. 7199, doi: 10.3390/su12177199.

Rühmkorf, A. (2017), "Global sourcing through foreign subsidiaries and suppliers: challenges for corporate social responsibility", In Research Handbook on Transnational Corporations, (pp. 194-220). 10.4337/9781783476916.00015

Sarkis, J., Cohen, M.J., Dewick, P. and Schröder, P. (2020), “A brave new world: lessons from the COVID19 pandemic for transitioning to sustainable supply and production", Resources, Conservation, and Recycling, p. 159, doi: 10.1016/j.resconrec.2020.104894.

Schiele, H. (2020), "Comparing public and private organisations in their quest to become a preferred customer of suppliers", Journal of Public Procurement, Vol. 20 No. 2.
Turning point in stopping global sourcing

233 
JGOSS

15,2

Schiele, H., Calvi, R. and Gibbert, M. (2012), "Customer attractiveness, supplier satisfaction and preferred customer status: introduction, definitions and an overarching framework", Industrial Marketing Management, Vol. 41 No. 8, pp. 1178-1185.

Schiele, H., Hoffmann, P. and Körber, T. (2020), "Synchronicity management: mitigating supply chain risks by systematically taking demand changes as starting point-a lesson from the covid 19 crisis”, IEEE Engineering Management Review, pp. 1-11.

Schiele, H., Horn, P. and Vos, B. (2011), "Estimating cost-saving potential from international sourcing and other sourcing levers: relative importance and trade-offs", International Journal of Physical Distribution and Logistics Management, Vol. 41 No. 3, pp. 315-336, doi: 10.1108/0960003 1111123813.

Smith, J.M. (1999), "Item selection for global purchasing", European Journal of Purchasing and Supply Management, Vol. 5 Nos 3/4, pp. 117-127, doi: 10.1016/S0969-7012(99)00016-7.

Steinle, C. and Schiele, H. (2008), "Limits to global sourcing? Strategic consequences of dependency on international suppliers: cluster theory, resource-based view and case studies", Journal of Purchasing and Supply Management, Vol. 14 No. 1, pp. 3-14, doi: 10.1016/J.PURSUP.2008.01.001.

Trent, R.J. and Monczka, R.M. (2003a), "International purchasing and global sourcing-what are the differences?", The Journal of Supply Chain Management, Vol. 39 No. 4, pp. 26-36, doi: 10.1111/ j.1745-493X.2003.tb00162.x.

Trent, R.J. and Monczka, R.M. (2003b), "Understanding integrated global sourcing", International Journal of Physical Distribution and Logistics Management, Vol. 33 No. 7, pp. 607-629, doi: 10.1108/09600030310499286.

Trent, R.J. and Monczka, R.M. (2005), "Achieving excellence in global sourcing", MIT Sloan Management Review, Vol. 47 No. 1, p. 24.

Tsai, M.C., Liao, C.H. and Han, C. S. (2008), "Risk perception on logistics outsourcing of retail chains: model development and empirical verification in Taiwan", Supply Chain Management: An International Journal, Vol. 13 No. 6, pp. 415-424.

Vrh, N. (2017), "The convergence in domestic value-added of exports in the EU", Post-Communist Economies, Vol. 29 No. 3, pp. 405-430.

Weigel, U. and Ruecker, M. (2017), The Strategic Procurement Practice Guide, Springer, 10, 978-973. 10.1007/978-3-319-57651-0

\section{Corresponding author}

Thomas Koerber can be contacted at: t.m.koerber@utwente.nl

For instructions on how to order reprints of this article, please visit our website: 